\title{
PEMBELAJARAN GRUP INVESTIGASI BERBANTUAN SPSS PADA MATA KULIAH STATISTIK UNTUK MENINGKATKAN KEMAMPUAN BERPIKIR KRITIS DAN SELF CONCEPT MATEMATIS MAHASISWA FKIP
}

\author{
Magy Gaspersz ${ }^{1 *}$, Reinhard Salamor ${ }^{2}$ \\ ${ }^{1,2}$ Program Studi Pendidikan Matematika Fakultas Keguruan dan Ilmu Pendidikan, Universitas Pattimura \\ Jalan Ir. M. Putuhena, Kampus Unpatti, Poka, Ambon, Indonesia \\ e-mail: ${ }^{1}$ magygspz.mg@ gmail.com; \\ Submitted: March 25, 2021 \\ Revised: April 24, 2021 \\ Accepted: May 8, 2021 \\ corresponding author*
}

\begin{abstract}
Abstrak
Penelitian ini bertujuan untuk menganalisis peningkatan kemampuan berpikir kritis dan self-concept matematis mahasiswa dengan menggunakan model pembelajaran group investigation (GI) berbantuan SPSS dan model pembelajaran konvensional. Tipe Penelitian ini adalah eksperimen kuasi dengan desain pre-test-post-test control group design. Populasi dalam penelitian ini adalah mahasiswa Jurusan Pendidikan Bahasa Indonesia. Melalui teknik purposive sampling, dua kelas dipilih sebagai sampel yaitu sebagai kelas eksperimen dan kelas kontrol. Instrumen yang digunakan berupa soal tes kemamuan berpikir kritis dan angket skala self concept. Analisis data kemampuan berpikir kritis matematis dan self concept menggunakan uji Mann Whitney dari nilai gain yang diperoleh. Hasil penelitian menunjukan bahwa, (1) Terdapat perbedaan kemampuan berpikir kritis dan self-concept matematis mahasiswa yang diajarkan dengan menggunakan model GI berbantuan SPSS dari mahasiswa yang diajarkan dengan menggunakan model konvensional; dan (2) Terdapat peningkatan kemampuan berpikir kritis kelas eksperimen sebesar 0,4 dan kelas kontol sebesar 0,3 sedangkan self-concept matematis mahasiswa yang pembelajarannya menggunakan model pembelajaran GI (eksperimen) yaitu sebesar 79,93 lebih baik daripada mahasiswa yang pembelajarannya menggunakan model pembelajaran konvensional (control) sebesar 65,12.
\end{abstract}

Kata Kunci: kemampuan berpikir kritis matematis, model pembelajaran group investigation, self concept matematis

\section{THE LEARNING OF GROUP INVESTIGATION ASSISTED BY SPSS IN STATISTICS COURSE TO IMPROVE CRITICAL THINKING SKILLS AND SELF-CONCEPT MATHEMATICS OF FKIP STUDENT}

\begin{abstract}
This study aims to analyze the improvement of students critical thinking skills and mathematical selfconcept using the learning of Group Investigation (GI) model assisted by SPSS and conventional models. This type of research is a quasi-experimental design with pre-test and post-test control group design. The population in this study were students of the Indonesian Language Education Department. Through purposive sampling technique, two classes were selected as samples, namely the experimental class and the control class. The instruments used were in the form of critical thinking ability test questions and selfconcept scale questionnaires. Data analysis of mathematical critical thinking skills and self-concept using the Mann Whitney test of the gain value obtained. The results showed that, (1) the improvement of students mathematical critical thinking skills whose learning using the SPSS-assisted GI model was better than students whose learning used conventional models; and (2) increasing the mathematical self-concept of students whose learning uses the GI learning model is better than students whose learning uses conventional learning models.
\end{abstract}

Keywords: mathematical critical thinking skills, group investigation model, mathematical self-concept

Copyright $(\odot$ Authors. This is an open access article distributed under the Attribution-NonCommercialShareAlike 4.0 International (CC BY-NC-SA 4.0), which permits unrestricted use, distribution, and reproduction in any medium, provided the original work is properly cited. 


\section{Pendahuluan}

Pengembangan kemampuan berpikir matematis harus didukung dengan sikap menghargai kegunaan matematika dalam kehidupan, yaitu memiliki rasa ingin tahu, perhatian, dan minat dalam mempelajari matematika, serta sikap ulet dan percaya diri dalam pemecahan masalah. Ditinjau dari kemampuan matematis, maka aktifitas pembelajaran matematika harus lebih ditekankan pada pengembangan kemampuan berpikir kritis. Menurut Liberna (2012:192), kemampuan berpikir kritis merupakan kemampuan yang sangat penting bagi setiap orang yang untuk memecahkan masalah yang dihadapi dalam kehidupan, yaitu dengan berpikir serius, aktif, dan teliti dalam menganalisis semua informasi yang diterima dengan suatu alasan yang rasional sehingga dilakukan dalam suatu tindakan yang benar. Terutama aktifitas pembelajaran pada Perguruan Tinggi, mahasiswa harus disiapkan dalam menghadapi persaingan di dunia kerja. Artinya sangat diharapkan perlu dilatih secara rutin untuk dapat menjawab soal-soal yang tergolong dalam hight order thinking skill (HOTS) sehingga mahasiswa mampu berpikir kritis. Menurut Budianti dan Purwaningsih (2018:2-3), berpikir kritis merupakan suatu kecakapan kognitif dalam menginvestigasi sebuah masalah, pertanyaan ataupun keadaan yang terjadi di sekitar agar dapat menarik suatu kesimpulan dan memecahkan permasalahan yang terjadi.

Pada hakekatnya aktivitas pembelajaran juga sangat mendukung seseorang berhasil. Keberhasilan dapat didukung dengan adanya perencanaan dan persiapan yang baik yaitu dalam memilih model pembelajaran yang sesuai dengan materi yang diajarkan. Bagi mahasiswa non MIPA atau mahasiswa di luar Program Studi Pendidikan Matematika, diketahui bahwa minat untuk mempelajari matematika sangat minim. Hal ini dapat dilihat dari hasil belajar mahasiswa pada pembelajaran mata kuliah dasar-dasar statistik pada program studi bahasa mencapai $67 \%$ berada pada kualifikasi cukup dan rendah. Padahal matematika merupakan dasar penting untuk dipelajari apalagi mata kuliah dasar-dasar statistik. Mata kuliah ini berkaitan dengan penulisan akhir mahasiswa untuk analisis data kuatitatif. Oleh karena itu para pendidik harus dapat memilih cara atau model pembelajaran sebagai proses keberhasilan mahasiswa, yaitu untuk mengembangkan berpikir kritis dan konsep diri yang positif terhadap matematika. salah satu model pembelajaran yang dapat digunakan yaitu model pembelajaran grup investigasi.
Menurut (Pranata, 2016), Group Investigation (GI) adalah model pembelajaran yang berbasis kelompok dengan memberikan peluang untuk berdiskusi dan berpikir kritis. Sehingga grup investigasi merupakan suatu model pembelajaran yang dapat membantu mahasiswa dalam kemampuan berpikir kritis dan self concept. Berdasarkan hasil penelitian Juniartina (2015) kemampuan berpikir kritis dapat ditingkatkan dengan menerapkan model pembelajaran group investigation. Pembelajaran dengan menerapkan grup investigasi berpeluang mengaktifkan para mahasiswa dalam belajar karena dalam aktifitas investigasi mahasiswa dilibatkan secara aktif, mulai dari memikirkan dan memilih strategi alternatif, sampai kepada keputusan untuk meyatakan solusi yang tepat sesuai dengan materi yang diajarkan.

Persoalan dalam dunia nyata yang dituangkan dalam mata kuliah Statistik dasar menjadi proyek bagi mahasiswa yang dituangkan dalam bentuk data. Oleh karena itu, program SPSS juga disiapkan untuk membantu penarikan kesimpulan dari suatu data yang diperoleh. Juniartina (2015) mengungkapkan bahwa pada pembelajaran konvensional dapat digunakan metode selain ceramah seperti praktikum dan dilengkapi atau didukung dengan penggunaan media, penekanannya tetap pada proses penerimaan pengetahuan (materi pelajaran) bukan pada proses pencarian dan konstruksi pengetahuan. Selain keterampilan berpikir kritis, pencapaian keberhasilan seseorang juga ditunjang oleh selfconcept. Menurut Tan dan Yates (Pamungkas 2015) bahwa self-concept yang berhubungan dengan pencapaian seseorang dalam bidang akademik disebut dengan self-concept akademik. Self-concept akademik mendeskripsikan cerminan diri seseorang terhadap suatu bidang studi tertentu (misalnya, saya suka matematika), serta aspek evaluasi persepsi dirinya (misalnya saya pandai matematika). Domain ini cenderung berfokus pada kompetensi skolastik, daripada sikap Strein. Selanjutnya Atwater mendefinisikan bahwa selfconcept merupakan keseluruhan gambaran diri, yang meliputi persepsi seseorang tentang diri, perasaan, keyakinan, dan nilai-nilai yang berhubungan dengan dirinya. Self-concept didefinisikan sebagai pandangan serta sikap sesesorang terhadap dirinya sendiri.

\section{Metode Penelitian}

Penelitian ini merupakan penelitian quasi experiment atau eksperimen semu yang dalam pelaksanaannya digunakan dua kelompok kelas, 
yaitu kelas eksperimen dan kelas kontrol. Maksud dari penggunaan kedua kelas ini ialah untuk melihat perbandingan peningkatan kemampuan berpikir kritis dan self concept. Kelompok eksperimen (kelas perlakuan) merupakan kelompok mahasiswa yang pembelajarannya menggunakan pembelajaran kooperatif tipe group investigasi (GI) dan kelompok kontrol (kelas pembanding) adalah kelompok mahasiswa yang pembelajarannya menggunakan model pembelajaran konvensional. Berdasarkan jenis penelitian yang dikemukakan, maka desain penelitian ini adalah "Pre-test-Post-test Control Group Design" .

Penelitian ini dilakakukan pada Mahasiswa Fakultas Keguruan dan Ilmu Pendidikan Universitas Pattimura Ambon program studi Pendidikan Bahasa dan Sastra Indonesia. Beberapa pertimbangan yang mendasar, agar penelitian ini dapat dilakukan secara efisien dan efektif, maka sampel ditentukan dengan teknik purposive sampling. Berdasarkan teknik ini, diperoleh sampel sebanyak dua kelas yaitu kelas sebagai kelas eksperimen sebanyak 25 mahasiswa dan kelas kontrol sebanyak 25 mahasiswa. Penelitian ini melibatkan dua variabel, yaitu variabel bebas dan variabel terikat. Upaya untuk memperoleh data dalam penelitian ini, yaitu dengan menggunakan 2 bentuk instrumen, yaitu tes dan non tes. Instrumen bentuk tes, terdiri dari seperangkat soal tes untuk mengukur kemampuan berpikir kritis dan instrumen bentuk non tes terdiri dari angket skala self-concept dan bahan ajar. Berikut adalah uraian secara terperinci instrumen-instrumen yang digunakan, yaitu: (1) Tes Kemampuan Awal Matematis (KAM), (2) tes kemampuan berpikir kritis (butir soal untuk mengukur kemampuan berpikir kritis, yaitu soal bentuk uraian) Sesuai dengan desain penelitian yang telah diungkapkan sebelumnya, maka tes kemampuan berpikir kritis dilakukan pada awal (pre-test) sebelum perlakukan dan ahkir (post-test) sesudah perlakuan. Butir soal tes yang diberikan baik kelas eksperimen maupun kelas kontrol sama. Penelitian ini menggunakan indikator keterampilan berpikir kritis dari penelitian Salamor (2013) adalah (1) indentifikasi konsep (concept), yaitu kemampuan mengidentifikasi keterkaitan konsep yang terpilih dengan unsur-unsur yang relevan untuk memecahkan masalah; (2) Penjelasan (explanation), yaiitu kemampuan menghadirkan argumen, mempertimbangkan sebuah prosedur, serta menulis hasil yang tepat; dan (3) membuat kesimpulan (inference making), yaitu kemampuan memberikan kesimpulan secara tepat terhadap data-data atau sebuah pernyataan (lewat sebuah proses pembuktian)
Data kemampuan berpikir kritis diperoleh dengan membuat pedoman penskoran terhadap jawaban mahasiswa untuk tiap butir soal dan untuk memperoleh soal tes yang baik maka soal tes tersebut harus dinilai validitas, reabilitas, daya pembeda dan tingkat kesukaran dan angket skala self concept yang digunakan adalah Skala Likert. Jawaban setiap item instrumen yang menggunakan Skala Likert dari pernyataan yang positif dan negatif terdiri dari lima kategori, yaitu sangat setuju (SS), setuju (S), netral (N), tidak setuju (TS), dan sangat tidak setuju (STT). Angket skala self concept dalam penelitian ini merupakan hasil adopsi dari penelitian yang dilakukan oleh Salamor (2013).

Data yang diperoleh dalam penelitian ini adalah data kuantitatif. Data ini diperoleh dari hasil pre-test dan post-test kemampuan berpikir kritis, yang diperiksa berdasarkan rubrik penilaian, $N$ gain, serta skala self concept dari kelas eksperimen maupun kelas kontrol. Data hasil pre-test, post-test, $N$-gain dan skala sikap self concept mahasiswa diolah dengan bantuan program Microsoft Excel dan software SPSS. Berdasarkan penskoran yang telah ditetapkan, maka data hasil tes kemampuan berpikir kritis diolah melalui tahapan-tahapan berikut: (1) membuat tabel skor pre-test dan posttest mahasiswa kelas eksperimen dan kelas control, dan (2) menentukan skor peningkatan kemampuan berpikir kritis matematis dengan rumus $\mathrm{N}$-gain ternormalisasi kemudian diinterpretasikan dengan menggunakan klasifikasi;

\section{Normalized Gain \\ $=\frac{\text { posttest score }- \text { pretest score }}{\text { maximum possible score }- \text { pretest score }}$}

Tahapan pengujian sebagai berikut.

a. Melakukan uji normalitas untuk mengetahui kenormalan data skor pre-test, post-test dan Ngain kemampuan berpikir kritis matematis menggunakan uji statistik KolmogorovSmirnov atau Shapiro Wilk.

b. Menguji homogenitas varians skor pre-test, post-test dan $\mathrm{N}$-gain kemampuan berpikir kritis matematis menggunakan uji Levene.

c. Setelah data memenuhi syarat normal dan homogen, selanjutnya dilakukan uji perbedaan rataan skor pre-test dan rataan $N$-gain dengan taraf signifikansi $(\alpha=0,05)$.

\section{Hasil dan Pembahasan}

\subsection{Hasil}

Data hasil pre-test dan post-test kemampuan berpikir kritis (KBK) dan skala self concept matematis (SCM) mahasiswa, baik 
mahasiswa yang mendapat pembelajaran dengan model group investigasi (GI) ataupun pembelajaran konvensional (PK) diolah dan dianalisis kemudian diperoleh hasil sebagai berikut.

\section{a. Kemampuan Berpikir Kritis (KBK)}

Analisis dilakukan dari data hasil pre-test dan post-test dari kelas GI dan kelas PK, selanjutnya

Tabel 1. Deskripsi Data Kemampuan Berpikir Kritis Matematis Kelas GI dan Kelas Konvensional

\begin{tabular}{|c|c|c|c|c|c|c|c|}
\hline \multirow{2}{*}{ Statistik } & \multicolumn{3}{|c|}{ Kelas Konvensional } & \multicolumn{5}{|c|}{ Kelas GI } \\
\cline { 2 - 4 } & Pre-test & Post-test & N-gain & $\mathrm{n}$ & Pre-test & Post-test & N-gain \\
\hline Max & 11 & 18 & 0,8 & & 9 & 17 & 0,53 \\
\hline Min & 0 & 2 & 0,10 & & 2 & 8 & 0,22 \\
\hline Sum & 142 & 232 & 6,70 & \multirow{2}{*}{25} & 150 & 330 & 10,15 \\
\hline $\bar{X}$ & 5,68 & 9,28 & 0,268 & & 6 & 13,2 & 0,406 \\
\hline SD & 2,996 & 4,077 & 0,157 & & 1,683 & 2,813 & 0,105 \\
\hline
\end{tabular}

Tabel 1 menunjukkan bahwa, rataan pre-test untuk semua kategori KAM relatif sama, masih tergolong rendah, baik kelas GI maupun konvensional dimana rataan pre-test mahasiswa pada kelas GI sebesar 5,68 dan mahasiswa pada kelas konvensional sebesar. Dari rataan kedua kelas tersebut, dapat disimpulkan bahwa kemampuan awal mahasiswa pada kedua kelas tersebut sama, dengan kualitas yang masih tergolong rendah. Rataan post-test menunjukkan hasil yang berbeda antara kelas GI dan kelas konvensional, dimana rataan mahasiswa kelas GI berbantuan SPSS sebesar 13,2 dan mahasiswa kelas konvensional sebesar 9,28. Artinya bahwa pembelajaran dengan model GI memberikan kontribusi yang baik bagi peningkatan berpikir kritis mahasiswa.

Kondisi yang sama juga terlihat pada hasil $N$-gain. $N$-gain secara keseluruhan dari kelas GI berbantuan SPSS dan kelas kontrol berselisih 0,138 . Hasil ini menunjukkan bahwa secara keseluruhan, peningkatan kemampuan berpikir kritis mahasiswa kelas GI lebih tinggi dari mahasiswa kelas konvensional.

1) Analisis Skor Pre-test Kemampuan Berpikir Kritis Matematis

a) Uji Normalitas. Uji normalitas skor pre-test dihitung dengan uji shapiro wilk dengan bantuan program SPSS pada taraf signifikansi $\alpha=0,05$. Jika nilai Signifikansi (p-value) lebih kecil dari 0,05 maka $\mathrm{H}_{0}$ ditolak dan jika nilai Signifikansi (p-value) sama atau lebih besar dari 0,05 maka $\mathrm{H}_{0}$ diterima. Hasil rangkuman uji normalitas disajikan pada Tabel 2 di bawah ini. dihitung gain ternormalisasi ( $N$-gain). Hasil rataan $N$-gain, akan memberikan gambaran peningkatan KBK mahasiswa yang mendapat pembelajaran GI dan mahasiswa yang mendapat Pembelajaran konvensional. Deskripsi pre-test, post-test dan $\mathrm{N}$-gain dapat dilihat pada Tabel 1 berikut.
Tabel 2. Data Hasil Uji Normalitas Data Pre-test KBK Matematis

\begin{tabular}{|c|c|c|c|c|}
\hline Kelas & Statistik & $\begin{array}{c}\text { Signifi } \\
\text { kansi }\end{array}$ & $\begin{array}{c}\text { Kesimpu } \\
\text { lan }\end{array}$ & Ket \\
\hline GI & 0,955 & 0,324 & $\begin{array}{c}\mathrm{H}_{0} \\
\text { diterima }\end{array}$ & Normal \\
\hline $\begin{array}{c}\text { Konvens } \\
\text { ional }\end{array}$ & 0,967 & 0,564 & $\begin{array}{c}\mathrm{H}_{0} \\
\text { diterima }\end{array}$ & Normal \\
\hline
\end{tabular}

$\mathrm{H}_{0}$ : Data pre-test KBK berdistribusi normal

$\mathrm{H}_{1}$ : Data pre-test $\mathrm{KBK}$ tidak berdistribusi normal

Signifikansi uji normalitas distribusi data pretest kemampuan berpikir kritis matematis yang dapat dilihat pada Tabel 2, nilainya Signifikansinya lebih besar dari 0,05 sehingga $\mathrm{H}_{0}$ diterima. Hasil ini menunjukkan bahwa, data skor pre-test kemampuan berpikir kritis matematis, mahamahasiswa kelas GI dan kelas konvensional berdistribusi normal.

b) Uji Homogenitas. Uji homogenitas skor pretest dihitung dengan uji levene dengan bantuan program SPSS dengan taraf signifikansi $\alpha=0,05$. Jika nilai Signifikansi (p-value) lebih kecil dari 0,05 maka $\mathrm{H}_{0}$ ditolak dan jika nilai Signifikansi (p-value) sama atau lebih besar dari 0,05 maka $\mathrm{H}_{0}$ diterima. Hasil rangkuman uji homogenitas disajikan pada Tabel 3 di bawah ini.

Tabel 3. Data Hasil Uji Homogenitas Data Pretes KBK Matematis

\begin{tabular}{|c|c|c|c|}
\hline F & Signifikansi & Kesimpulan & Ket \\
\hline 9,314 & 0,004 & $\mathrm{H}_{0}$ ditolak & $\begin{array}{c}\text { Tidak } \\
\text { Homogen }\end{array}$ \\
\hline
\end{tabular}

$\mathrm{H}_{0}$ : Varians data KBK matematis kelas GI dan konvensional homogen

$\mathrm{H}_{1}$ : Varians data KBK matematis kelas GI dan konvensional tidak homogen

Signifikansi uji homogenitas varians data pretest kemampuan berpikir kritis matematis dapat 
dilihat pada Tabel 3, nilai Signifikansinya lebih kecil dari 0,05 sehingga $\mathrm{H}_{0}$ ditolak. Hasil ini menunjukkan bahwa, varians data pre-test kemampuan berpikir kritis matematis, mahasiswa kelas GI dan kelas konvensional tidak homogen.

c) Uji Perbedaan Rataan Pre-Test Kemampuan Berpikir Kritis. Setelah dilakukan uji prasyarat kenormalan dan homogenitas, maka dilanjutkan dengan uji perbedaan rataan pretest dengan menggunakan uji Mann Whitney (variansi tidak homogen) dengan bantuan program SPSS. Tabel 4 menunjukkan rangkuman hasil uji perbedaan rataan skor pre-test pada taraf signifikansi $\alpha=0,05$. Jika nilai signifikansi (p-value) lebih kecil dari 0,05 maka $\mathrm{H}_{0}$ ditolak, sedangkan jika nilai Signifikansi (p-value) sama atau lebih besar dari 0,05 maka $\mathrm{H}_{0}$ diterima.

Tabel 4. Data Hasil Uji Perbedaan Rataan Data Pretest KBK Matematis

\begin{tabular}{|c|c|c|c|}
\hline $\begin{array}{c}\text { Mann } \\
\text { Whitney }\end{array}$ & $\begin{array}{c}\text { Sig } \\
\text { (2-tailed) }\end{array}$ & Ket & Kesimpulan \\
\hline 297,00 & 0,761 & $\begin{array}{c}\mathrm{H}_{0} \\
\text { Diterima }\end{array}$ & $\begin{array}{c}\text { Tidak } \\
\text { Terdapat } \\
\text { Perbedaan }\end{array}$ \\
\hline
\end{tabular}

Hasil independent sample test pada Tabel 4 di atas, menunjukkan bahwa $\mathrm{H}_{0}$ diterima. Artinya, tidak terdapat perbedaan yang signifikan antara skor pre-test kemampuan berpikir kritis matematis mahamahasiswa kelas GI dan kelas konvensional. Dengan demikian kemampuan awal kedua kelas sama.

2) Analisis Peningkatan Kemampuan Berpikir Kritis Matematis (Nilai Gain)

a) Uji Normalitas. Uji normalitas Nilai Gain dihitung dengan uji Shapiro Wilk dengan bantuan program SPSS pada taraf signifikansi $\alpha=0,05$. Hasil rangkuman uji normalitas disajikan pada Tabel 5 di bawah ini.

Tabel 5. Data Hasil Uji Normalitas Data N- Gain KBK Matematis

\begin{tabular}{|c|c|c|c|c|}
\hline Kelas & Statistik & Sig. & Kesimpulan & Ket \\
\hline GI & 0,955 & 0,324 & $\mathrm{H}_{0}$ diterima & Normal \\
\hline Kon & 0,967 & 0,564 & $\mathrm{H}_{0}$ diterima & Normal \\
\hline
\end{tabular}

$\mathrm{H}_{0}$ : Data Gain KBK berdistribusi normal

$\mathrm{H}_{1}$ : Data Gain KBK tidak berdistribusi normal

Signifikansi uji normalitas distribusi data Gain kemampuan berpikir kritis matematis yang dapat dilihat pada Tabel 5, nilainya Signifikansinya lebih besar dari 0,05 sehingga $\mathrm{H}_{0}$ diterima. Hasil ini menunjukkan bahwa, data Gain kemampuan berpikir kritis matematis, mahamahasiswa kelas GI dan kelas konvensional berdistribusi normal.

b) Uji Homogenitas. Uji homogenitas skor pretest dihitung dengan uji levene dengan bantuan program SPSS dengan taraf signifikansi $\alpha=0,05$. Hasil rangkuman uji homogenitas disajikan pada Tabel 6 di bawah ini.

Tabel 6. Data Hasil Uji Homogenitas Data Pretes KBK Matematis

\begin{tabular}{|c|c|c|c|}
\hline F & Signifikansi & Kesimpulan & Ket \\
\hline 2,329 & 0,134 & $\mathrm{H}_{0}$ diterima & $\begin{array}{c}\text { Tidak } \\
\text { Homogen }\end{array}$ \\
\hline
\end{tabular}

$\mathrm{H}_{0}$ : Varians data KBK matematis kelas GI dan konvensional homogen

$\mathrm{H}_{1}$ : Varians data KBK matematis kelas GI dan konvensional tidak homogen

Tabel 6 menunjukkan rangkuman hasil uji perbedaan rataan skor gain pada taraf signifikansi $\alpha=0,05$. Jika nilai signifikansi ( $\mathrm{p}$-value) lebih kecil dari 0,05 maka $\mathrm{H}_{0}$ ditolak, sedangkan jika nilai Signifikansi (p-value) sama atau lebih besar dari 0,05 maka $\mathrm{H}_{0}$ diterima.

Tabel 7. Data Hasil Uji Perbedaan Rataan Data $N$-Gain KBK Matematis

\begin{tabular}{|c|c|c|c|}
\hline $\begin{array}{c}\text { Mann } \\
\text { Whitney }\end{array}$ & $\begin{array}{c}\text { Sig } \\
\text { (2-tailed) }\end{array}$ & Ket & Kesimpulan \\
\hline 162,50 & 0,04 & $\begin{array}{c}\mathrm{H}_{0} \\
\text { Ditolak }\end{array}$ & $\begin{array}{c}\text { Terdapat } \\
\text { Perbedaan }\end{array}$ \\
\hline
\end{tabular}

Hasil independent sample test pada Tabel 7 , menunjukkan bahwa $\mathrm{H}_{0}$ tolak. Artinya, terdapat perbedaan yang signifikan antara kemampuan berpikir kritis matematis mahasiswa kelas GI dan kelas konvensional. Dengan kata lain, peningkatan kemampuan mahasiswa kelas GI berbantuan SPSS lebih baik dari mahasiswa kelas konvensional berdasarkan pembelajaran.

\section{b. Self Concept Matematis (SCM)}

Pemberian angket self concept matematis kepada mahasiswa, dilakukan sebelum dan sesudah pembelajaran, baik kepada kelas GI maupun kelas konvensional. Data skala yang diperoleh merupakan data ordinal, sehingga untuk melanjutkan dengan menguji statistik, data ordinal harus diubah kedalam data interval dengan Method of Successive Interval. Tabel 8 menunjukkan rangkuman data self concept matematis awal (sebelum pembelajaran) pada kelas GI dan kelas konvensional. 
Tabel 8. Deskripsi Data Self Concept Matematis

\begin{tabular}{|c|c|c|c|c|c|}
\hline \multirow{2}{*}{$\begin{array}{l}\text { Statis } \\
\text { tik }\end{array}$} & \multicolumn{2}{|c|}{$\begin{array}{c}\text { Kelas } \\
\text { Konvensional }\end{array}$} & \multicolumn{3}{|c|}{ Kelas GI } \\
\hline & $\begin{array}{c}\text { Sebelu } \\
\mathrm{m}\end{array}$ & sesudah & $\mathbf{n}$ & $\begin{array}{c}\text { Sebel } \\
\text { um }\end{array}$ & $\begin{array}{c}\text { Sesud } \\
\text { ah }\end{array}$ \\
\hline Max & 70 & 79 & \multirow{4}{*}{25} & 69 & 91 \\
\hline Min & 45 & 60 & & 47 & 56 \\
\hline Sum & 1458 & 1628 & & 1481 & 1998 \\
\hline $\bar{X}$ & 58,32 & 65,12 & & 59,24 & 79,93 \\
\hline
\end{tabular}

1) Analisis Skor Self Concept Matematis (SCM) Sebelum Pembelajaran

Analisis self concept matematis sebelum pembelajaran dilakukan untuk melihat apakah self concept matematis sebelum pembelajaran pada kedua kelas sama. Sebelum data dianalisis, terlebih dahulu dilakukan uji prasyarat.

a) Uji Normalitas. Uji normalitas skor self concept matematis dihitung dengan uji Kolmogorov-Smirnov dengan bantuan program SPSS 20 dengan taraf signifikansi $\alpha$ $=0,05$. Hasil rangkuman uji normalitas disajikan pada Tabel 9 berikut ini.

Tabel 9. Data Hasil Uji Normalitas Skor SCM

\begin{tabular}{|l|c|c|l|}
\hline \multirow{2}{*}{ Kelas } & \multicolumn{2}{|c|}{$\begin{array}{c}\text { Kolmogorov- } \\
\text { Smirnov }\end{array}$} & \multirow{2}{*}{ Kesimpulan } \\
\cline { 2 - 3 } & Statistic & Sig. & \\
\hline GI & 0,106 & 0,200 & $\begin{array}{l}\text { Data } \\
\text { Berdistribusi } \\
\text { Normal }\end{array}$ \\
\hline Konvensional & 0,150 & 0,121 & $\begin{array}{l}\text { Data } \\
\text { Berdistribusi } \\
\text { Normal }\end{array}$ \\
\hline
\end{tabular}

$\mathrm{H}_{0}$ : skor SCM berdistribusi normal

$\mathrm{H}_{1}$ : skor SCM tidak berdistribusi normal

Tabel 9 menunjukkan bahwa, data skor self concept matematis mahamahasiswa kelas GI dan kelas konvensional berdistribusi normal.

b) Uji Homogenitas. Homogenitas varians skor self concept matematis menggunakan uji Levene dengan bantuan program SPSS pada taraf signifikansi $\alpha=0,05$. Rangkuman hasil perhitungan uji homogenitas disajikan pada Tabel 10 berikut.

Tabel 10. Data Hasil Uji Homogenitas Varians Skor Self Concept Matematis

\begin{tabular}{|c|c|c|}
\hline $\begin{array}{c}\text { Levene } \\
\text { Statistic }\end{array}$ & Sig. & Kesimpulan \\
\hline 10,33 & 0,002 & Tidak homogen \\
\hline
\end{tabular}

$\mathrm{H}_{0}$ : varians skor SCM kelas GI dan Konvensional homogen

$\mathrm{H}_{1}$ : varians skor SCM kelas GI dan Konvensional tidak homogeny
Tabel 10 menunjukkan bahwa, varians skor self concept matematis memperlihatkan nilai Signifikansinya lebih kecil dari 0,05 sehingga $\mathrm{H}_{0}$ ditolak. Artinya skor self concept matematis mahasiswa kelas GI dan kelas konvensional berasal dari varians yang tidak homogen.

c) Uji perbedaan Self Concept Matematis (SCM) sebelum Pembelajaran. Data skor Self Concept yang telah memenuhi uji prasyarat kenormalan dan homogenitas, maka dilanjutkan pada uji perbedaan skor Self Concept dengan menggunakan uji Mann Whitney pada taraf signifikansi $\alpha=0,05$ (variansi tidak homogen). Jika nilai Signifikansi (p-value) lebih kecil dari 0,05 maka $\mathrm{H}_{0}$ ditolak, sedangkan jika nilai Signifikansi (p-value) sama atau lebih besar dari 0,05 maka $\mathrm{H}_{0}$ diterima. Rangkuman hasil uji perbedaan rataan skor Self Concept dapat dilihat pada Tabel 11 di bawah ini.

Tabel 11. Uji Perbedaan Rataan Skor SCM

\begin{tabular}{|c|c|c|c|}
\hline $\begin{array}{c}\text { Mann } \\
\text { Whitney }\end{array}$ & $\begin{array}{c}\text { Sig } \\
\text { (2-tailed) }\end{array}$ & Ket & Kesimpulan \\
\hline 293,50 & 0,712 & $\begin{array}{c}\mathrm{H}_{0} \\
\text { Diterima }\end{array}$ & $\begin{array}{c}\text { Tidak } \\
\text { Terdapat } \\
\text { Perbedaan }\end{array}$ \\
\hline
\end{tabular}

Sesuai hasil uji pada table 11 di atas, menunjukkan bahwa $\mathrm{H}_{0}$ ditolak. Hal ini menunjukkan bahwa $\mathrm{H}_{0}$ diterima, artinya rataan skor self concept matematis mahamahasiswa kelas GI sama dengan kelas konvensional.

\section{2) Analisis Skor Self Concept Matematis (SCM)} Sesudah Pembelajaran

Analisis self concept matematis sesudah pembelajaran dilakukan untuk membuktikan hasil yang telah diperoleh sebelumnya, yaitu untuk melihat apakah self concept matematis sesudah pembelajaran pada kedua kelas berbeda secara signifikan? Sebelum data dianalisis, terlebih dahulu dilakukan uji prasyarat.

a) Uji Normalitas. Uji normalitas skor self concept matematis dihitung dengan uji Kolmogorov-Smirnov dengan bantuan program SPSS dengan taraf signifikansi $\alpha=$ 0,05. Hasil rangkuman uji normalitas disajikan pada Tabel 12 menunjukkan bahwa, skor self concept matematis mahasiswa kelas GI dan kelas konvensional berdistribusi normal. 
Tabel 12. Data Hasil Uji Normalitas Skor SCM

\begin{tabular}{|l|c|c|l|}
\hline \multirow{2}{*}{ Kelas } & \multicolumn{2}{|c|}{$\begin{array}{c}\text { Kolmogorov- } \\
\text { Smirnov }\end{array}$} & \multirow{2}{*}{ Kesimpulan } \\
\cline { 2 - 3 } & Statistic & Sig. & \\
\hline GI & 0,146 & 0,146 & $\begin{array}{l}\text { Data } \\
\text { Berdistribusi } \\
\text { Normal }\end{array}$ \\
\hline Konvensional & 0,161 & 0,070 & $\begin{array}{l}\text { Data } \\
\text { Berdistribusi } \\
\text { Normal }\end{array}$ \\
\hline
\end{tabular}

$\mathrm{H}_{0}$ : data SCM berdistribusi normal

$\mathrm{H}_{1}$ : data SCM tidak berdistribusi normal

b) Uji Homogenitas. Homogenitas varians skor self concept matematis menggunakan uji Levene dengan bantuan program SPSS pada taraf signifikansi $\alpha=0,05$. Rangkuman perhitungan uji homogenitas pada Tabel 13 menunjukkan bahwa, varians skor self concept matematis memperlihatkan nilai Signifikansinya lebih kecil dari 0,05 sehingga $\mathrm{H}_{0}$ ditolak. Artinya skor self concept matematis mahasiswa kelas GI dan kelas konvensional berasal dari varians yang tidak homogen.

Tabel 13. Data Hasil Uji Homogenitas Varians Skor SCM

\begin{tabular}{|c|c|c|}
\hline Levene Statistic & Sig. & Kesimpulan \\
\hline 18,266 & 0,00 & Tidak homogen \\
\hline
\end{tabular}

$\mathrm{H}_{0}$ : varians skor SCM kelas GI dan Konvensional homogen

$\mathrm{H}_{0}$ : varians skor SCM kelas GI dan Konvensional tidak homogen

Rangkuman hasil uji perbedaan rataan skor Self Concept dapat dilihat pada Tabel 14 menunjukkan bahwa $\mathrm{H}_{0}$ ditolak. Artinya ada perbedaan antara self concept matematis mahasiswa kelas GI dan kelas konvensional. Tentunya peningkatan self concept matematis mahasiswa yang lebih tinggi ada pada mahasiswa kelas GI yaitu dengan rerata sebesar 79,93 sedangkan mahasiswa pada kelas konvensional yaitu 65,12 .

Tabel 14. Uji Perbedaan Rataan Skor SCM

\begin{tabular}{|c|c|c|c|}
\hline $\begin{array}{c}\text { Mann } \\
\text { Whitney }\end{array}$ & $\begin{array}{c}\text { Sig } \\
\text { (2-tailed) }\end{array}$ & Ket & Kesimpulan \\
\hline 69,50 & 0,00 & $\begin{array}{c}\mathrm{H}_{0} \\
\text { Ditolak }\end{array}$ & $\begin{array}{c}\text { Terdapat } \\
\text { Perbedaan }\end{array}$ \\
\hline
\end{tabular}

\subsection{Pembahasan}

Model pembelajaran group investigation (GI) dan pembelajaran konvensional adalah dua model pembelajaran berbeda yang diterapkan pada 2 kelas serta dibandingkan kontribusinya terhadap peningkatan kemampuan berpikir kritis dan self concept matematis mahasiswa. Hasil penelitian yang telah dianalisis sebelumnya menunjukkan bahwa, pembelajaran GI berbantuan SPSS dapat meningkatkan kemampuan berpikir kritis mahasiswa. Hasil penelitian ini dapat ditunjukan melalui perolehan skor $\mathrm{N}$-gain kelas GI sebesar 0,4 lebih besar dari kelas konvensional yaitu 0,3. Meskipun peningkatan tersebut masih dalam klasifikasi sedang, namun hasil uji statistik menunjukkkan bahwa, peningatan kemampuan beripikir kritis mahasiswa pada kelas GI berbantuan SPSS lebih baik dari mahasiswa kelas konvensional.

Secara statistik, hasil yang sama juga diperoleh pada self concept matematis mahasiswa. Rataan self concept mahasiswa kelas GI berbantuan SPSS dan konvensional sebelum pembelajaran relatif sama dan berada pada kategori negatif. Begitupun juga jika ditinjau dari ketiga aspek, aspek yang berada pada kategori positif hanya aspek manfaat. Sedangkan Rataan self concept mahasiswa kelas GI dan konvensional sebelum pembelajaran, menunjukkan peningkatan. Namun, peningkatan self concept mahasiswa kelas GI berbantuan SPSS lebih tinggi dari mahasiswa kelas konvensional. Rataan self concept matematis mahasiswa kelas GI sebesar 79,93 dan pembelajaran konvensional sebesar 65,12. Hasil uji statistik terhadap data skala self-concept matematis menunjukkan bahwa, self-concept matematis mahasiswa yang mendapatkan pembelajaran GI secara signifikan lebih baik daripada mahasiswa yang mendapatkan pembelajaran konvensional. Fakta ini menunjukkan bahwa, peningkatan prestasi mahasiswa dalam matematika juga sangat dipengaruhi oleh sikap mahasiswa yang positif terhadap matematika. Ayodele (2011) mengungkapkan bahwa mahasiswa yang memiliki self concept yang positif terhadap matematika, prestasi belajar matematika pun lebih baik.

Masalah yang diberikan dalam pembelajaran pada kelas GI bukan hanya menuntut mahasiswa untuk membuktikan sehingga mahasiswa dapat menemukan konsep baru dalam proses investigasi yang dilakukan. Oleh karena itu, hendaknya mahasiswa terus diberikan kesempatan, pelajaran yang diperoleh bukan sekedar menghafal namun dapat memahami dengan baik. Peran dosen sebagai fasilitator memang bukan hal yang mudah untuk dilakukan. Dalam penelitian ini, dosen harus mempersiapkan diri sebaik-baiknya karena harus mengahadapi kelas yang penuh keributan dan mahasiswa terus meminta pertolongan dosen jika mendapat hambatan. Namun pertolongan yang diberikan oleh dosen, hanya sebagai fasilitator, 
tidak memberikan jawaban sepenuhnya. Hal ini sama dengan yang diungkapkan Thelen (Joyce, dkk., 2009) yang menyebutkan bahwa, dosen harus memandu aktivitas agar lebih bermakna, sehingga pemahaman mahasiswa muncul dari pengalaman lewat kegiatan investigasi.

Berbeda halnya dengan kelas konvensional, dimana dosen yang menerangkan konsep dan akhirnya memberikan contoh dan soal untuk mahasiswa kerjakan di papan tulis. Kondisi seperti ini terus berlangsung selama penelitian, yang menyebabkan mahasiswa yang pandai saja yang mampu menyerap atau materi yang diberikan, sedangkan mahasiswa yang lainya terlihat pasif. Proses pembelajaran seperti ini, tidak mempu menghasilkan mahasiswa yang dapat berpikir kritis dan mempunyai konsep diri yang positif terhadap matematika. Paul Ernest (Turmudi, 2009) menyebutkan bahwa, tugas-tugas belajar di kelas mengajarkan para mahasiswa untuk melakukan prosedur simbolik tertentu, untuk bekerja namun tidak berpikir, sehingga menjadi automatons, bukan menjadi mahasiswa yang kritis dan mandiri.

Perbedaan pembelajaran GI berbantuan SPSS dan konvensional dalam hal peningkatan kemampuan berpikir kritis dan self concept mahasiswa berbeda signifikan. Hal ini dibuktikan melalui hasil penelitian yang mengungkapkan bahwa peningkatan kemampuan berpikir kritis dan self-concept matematis mahasiswa yang mendapat pembelajaran GI berbantuan SPSS lebih baik dari mahasiswa yang mendapat pembelajaran konvensional. Hai ini berarti, pembelajaran GI berbantuan SPSS memberikan kontribusi yang besar untuk menghasilkan mahasiswa yang berpikir kritis dan mempunyai konsep diri yang lebih positif terhadap pembelajaran matematika. Hal ini senada dengan pendapat Artini (2015) menyatakan bahwa model pembelajaran Group Investigation merupakan pembelajaran berbasis kelompok yang memberikan peluang kepada siswa untuk berdiskusi, berfikir kritis, dan dapat bertanggung jawab dalam pembelajaran tersebut. Demikian juga dengan pendapat Fahradina, dkk (2014) bahwa Investigasi kelompok adalah salah satu model pembelajaran kooperatif yang dapat memberikan kondisi belajar aktif. Kontribusi dari model pembelajaran GI berbantuan SPSS dan konvensional, jelas memberikan hasil yang berbeda. Hasil uji statistik dapat menunjukkan bahwa, penerapan model pembelajaran GI berbantuan SPSS memberikan kontribusi yang baik terhadap peningkatan kemampuan berpikir kritis matematis mahasiswa dan dapat mengembangkan self concept matematis mahasiswa menjadi positif.
Hasil analisis data menunjukkan bahwa, self concept matematis mahasiswa sebelum pembelajaran pada kelas GI maupun konvensional relatif sama dan berada pada kategori negatif. Hal ini mengindikasikan bahwa pelajaran matematika adalah salah satu pelajaran yang kurang diminati para mahasiswa Program Bahasa dan Sastra Indonesia. Jika ditinjau dari aspek keyakinan, sikap, dan manfaat, maka yang berada pada kategori positif hanyalah aspek manfaat. Hal ini berarti bahwa para mahasiswa sadar akan pentingnya matematika, baik aplikasi dalam kehidupan sehari-hari maupun manfaat bagi masa depan. Aspek manfaat ini dapat memberikan sebuah ruang bagi dosen untuk bertindak memperbaiki aspek keyakinan dan sikap terhadap matematika, agar mahasiswa lebih tertarik dan lebih berminat untuk mempelajari matematik. Grigutsch (Yara, 2010) menyatakan bahwa komponen penting dari self concept dalam matematika yaitu pengetahuan dan minat.

Pemilihan model dan metode yang tepat adalah salah satu jalan keluarnya. Hal ini dapat terlihat dari rataan skor self-concept matematis yang mengalami peningkatan setelah mendapat pelajaran dengan model GI Berbantuan SPSS. Rataan skor self concept matematis kelas GI lebih tinggi dari kelas konvensional. Sesuai dengan hasil uji statistik, dapat dibuktikan bahwa self-concept matematis kelas GI berbantuan SPSS lebih lebih baik dari mahasiswa kelas konvensional. Cara belajar yang berbeda dengan sebuah model pembelajaran yang inovatif bukanlah satu-satunya cara dalam mengembangkan self-concept mahasiswa. Dosen harus dapat menjadi figur maupun model yang dapat memotivasi mahasiswa menjadi pribadi yang semangat, tidak mudah menyerah dalam memecahkan sebuah persoalan. Self-concept mahasiswa dalam belajar matematika akan lebih terbentuk dengan baik, jika dosen dapat memberikan kesempatan dan menuntun mahasiswa untuk memperoleh sebuah jawaban yang tepat. Hal ini tentu sangat berpengaruh terhadap Self-concept mahasiswa, dimana Self concept mahasiswa selalu positif dalam mempelajari matematika. Mahasiswa akan mengembangkan sikap yang percaya diri, semangat yang tinggi, dan bertanggung jawab atas sebuah masalah yang dipecahkan. Jika hal ini terjadi di kelas, maka harapan mahasiswa terhadap prestasi dalam matematika akan semakin baik.

Hal ini berarti bahwa, peningkatan self concept mahasiswa dapat menunjang aktifitas aktif mahasiswa di kelas sehingga dapat menunjang prestasi akademiknya. Menurut Rahman (2012) self-concept meliputi kognisi seseorang mengenai tanggapan penilaian yang dilakukannya tentang 
persepsi aspek-aspek dirinya, suatu pemahaman tentang gambaran orang lain mengenai dirinya, dan kesadaran penilaian dirinya yaitu gagasannya tentang bagaimana seharusnya dirinya dan bagaimana dilakukannya.

\section{Kesimpulan}

Berdasarkan hasil penelitian yang diperoleh maka Berdasarkan hasil penelitian yang diperoleh maka peneliti memberikan kesimpulan sebagai berikut: (1) hasil penelitian yang telah dianalisis menunjukkan bahwa, pembelajaran GI berbantuan SPSS dapat meningkatkan kemampuan berpikir kritis mahasiswa. Hasil penelitian ini dapat ditunjukan melalui perolehan skor N-gain kelas GI sebesar 0,4 lebih besar dari kelas konvensional yaitu 0,3. Meskipun peningkatan tersebut masih dalam klasifikasi sedang, namun hasil uji statistik menunjukkkan bahwa, peningkatan kemampuan beripikir kritis mahasiswa yang kelas GI berbantuan SPSS lebih baik dari mahasiswa kelas konvensional. (2) peningkatan self-concept mahasiswa kelas GI berbantuan SPSS lebih tinggi dari mahasiswa kelas konvensional. Rataan selfconcept matematis mahasiswa kelas GI sebesar 79,93 dan pembelajaran konvensional sebesar 65,12 . Hasil uji statistik terhadap data skala selfconcept matematis menunjukkan bahwa, selfconcept matematis mahasiswa yang mendapatkan pembelajaran GI secara signifikan lebih baik daripada mahasiswa yang mendapatkan pembelajaran konvensional.

\section{Daftar Pustaka}

Artini, dkk. (2015). Penerapan Model Pembelajaran Kooperatif Tife Group Investigation Untuk Meningkatkan Aktivitas dan Hasil Belajar IPA pada Siswa Kelas VI SD Impres 1 Tondo. Universitas Tadulako.e-Jurnal Mitra Sains Vol. 3. No. 1, Januari 2015.

Ayodele, J.O. (2011). Self-concept and Performance of Secondary School Students in Mathematics. Journal of Educational and Developmental Psychology. 1(1), 49-54.

Budianti, Y \& Purwaningsih, A. (2018). Meningkatkan Kemampuan Berpikir Kritis dengan Menggunakan Model Cooperative Tipe Group Investigation Pada Siswa Kelas V SD Negeri
Harapan Jaya 1 Bekasi Utara. Jurnal Pedagogik Vol. VI, No. 1, Februari 2018

Fahradina, N, dkk. (2014). Peningkatan Kemampuan Komunikasi Matematis dan Kemandirian Belajar Siswa SMP dengan Menggunakan Model Investigasi Kelompok. Jurnal Didaktik Matematika ISSN: 2355-4185 Vol 1. No 1. Sept 2014

Joyce, B., Weil, M., \& Calhoun, E. (2009). Models of Teaching. Model-Model Pengajaran (Terjemahan edisi delapan). Yogyakarta: Pustaka Pelajar

Juniartina, P. P (2015). Pengaruh Model Pembelajaran Kooperatif Group Investigation Terhadap Pemahaman Konsep dan Kemampuan Berpikir Kritis Siswa Kelas XI IA SMA Negeri 4 Singaraja. Proceedings Seminar Nasional FMIPA UNDIKSHA V Tahun 2015. Hal 188194

Liberina, H. (2012). Peningkatan Kemampuan Berpikir Kritis Matematis Siswa Melalui Penggunaan Metode Improve Pada Materi Sistem Persamaan Linear Dua Variabel. Jurnal Formatif Vol 2, Nomor 3, Hal 190-197. ISSN:2088-351X

Pamungkas, S. A. (2015). Kontribusi Self concept Matematis Dan Mathematics Anxiety Terhadap Hasil Belajar Mahasiswa. Jurnal Dinamika Pendidikan (JDP). Volume 8, Nomor 2, Juli 2015. Hal 55-60.

Pranata, E. (2016). Implementasi Model Pembelajaran Group Investigation (GI) Berbantuan Alat Peraga untuk Meningkatkan Kemampuan Pemahaman Konsep Matematika. Jurnal Pendidikan Matematika Indonesia Vol. 1 No 1 bulan Maret 2016. Halaman 34-38 p-ISSN: 2477-5967 e-ISSN: 2477-8443

Rahman, R. (2012). Hubungan antara self-concept terhadap matematika dengan kemampuan berpikir kreatif matematika siswa. Infinity Jurnal Ilmiah Program Studi Matematika STKIP Siliwangi Bandung, Vol 1, No.1, Februari 2012. Hal 19-30 e-ISSN: 2460-9285

Salamor, R. (2013). Pembelajaran Group Investigation dalam upaya peningkatan kemampuan berpikir dan Self concept Matematis siswa Sekolah Menengah Pertama. Thesis. Bandung: UPI

Turmudi. (2009). Landasan Filsafat dan Teori Pembelajaran Matematika; Berparadigma Eksplorasi dan Investigasi. Jakarta: Leuser Cita Pustaka

Yara, P.O. (2010). Student's Self-Concept and Mathematics Achievement in Some Secondary school on Southwestern Nigeria. European Journal of Social Sciences, Vol 13, No 1, 127132 